\title{
Prenatal Sonographic Diagnosis of Meckel-Gruber Syndrome: A Case Report
}

\section{Meckel-Gruber Sendromunun Prenatal Sonografik Tanısı: Olgu Sunumu}

\author{
Seyit Ahmet EROL ${ }^{1}$ iD, Ayșe KIRBAȘ ${ }^{2}$ \\ 1 Department of Perinatology, Ankara City Hospital, Ankara, Turkey \\ 2 Department of Perinatology, Medicana International Hospital, Ankara, Turkey
}

ORCID ID: Seyit Ahmet Erol 0000-0002-2494-4896, Ayșe Kırbaș 0000-0002-4522-9461

Cite this article as: Erol SA and Kırbaș A. Prenatal Sonographic Diagnosis of Meckel-Gruber Syndrome: A Case Report. Med J West Black Sea. 2021;5(1):110-113.

Corresponding Author Seyit Ahmet Erol

E-mail

gyn.aerol@gmail.com
Received

31.08.2020

Revision

20.10.2020

Accepted

12.12.2020

\section{ABSTRACT}

Aim: We report a case in which the prenatal diagnosis of Meckel Gruber (MGS) syndrome was feasible by ultrasonography in the first trimester

Case report: A 26 years old woman in her second pregnancy was referred to our perinatology clinic at 13th gestational week with a suspicion of encephalocele. The fetal kidneys were hyperechogenic and enlarged, consistent with bilateral cystic dysplasia. The hands were compatible with polydactyly. According to the sonographic findings, our prenatal sonographic diagnosis was Meckel-Gruber syndrome.

Conclusion: MGS is a lethal disorder. In addition, it is a pathology with a high risk of recurrence (25\%) due to its autosomal recessively inheritance. Especially in families with anomaly history in previous pregnancies, early ultrasonographic evaluation and genetic counseling to be given to the family afterwards are important in management.

Keywords: Meckel-Gruber, Encephalocele, Polydactyly, Dysplastic kidney

\section{ÖZ}

Amaç: Ultrasonografi ile erken dönem, ilk trimesterde Meckel-Gruber (MGS) sendromu prenatal tanısı konulan olgu sunulmuştur.

Olgu sunumu: 26 yaşında ikinci gebeliği olan gebe hasta, ensefalosel şüphesiyle 13. gebelik haftasında perinatoloji kliniğimize sevk edildi. Fetal böbrekler, bilateral kistik displazi ile uyumlu olarak hiperekojenik ve genişlemişti. Ellerde polidaktili ile uyumlu görünüm izlendi. Ultrason bulgularımıza göre, prenatal sonografik tanımız Meckel-Gruber sendromuydu.

Sonuç: MGS ölümcül bir hastalıktır. Ayrıca otozomal resesif geçişli olması nedeniyle tekrarlama riski yüksek (\%25) bir patolojidir. Özellikle daha önceki gebeliklerinde anomali öyküsü olan ailelerde erken ultrasonografik değerlendirme ve sonrasında aileye verilecek genetik danışmanlık yönetimde önemlidir.

Anahtar Sözcükler: Meckel-Gruber, Ensefalosel, Polidaktili, Displastik böbrek 


\section{INTRODUCTION}

Meckel-Gruber syndrome (MGS) is an unusual and lethal autosomal recessive disease characterized with a classical triad of encephalocele (occipital in generally), bilateral fetal renal cystic dysplasia and postaxial polydactyly (1). At least two of the major antenatal ultrasound (USG) findings should be present for the correct diagnosis of this syndrome $(2,3)$.

In approximately $57 \%$ of the cases, three findings can be seen together (4). In addition to these classical findings, central nervous system findings such as Dandy-Walker malformation, Arnold Chiari malformation, microcephaly, hydrocephalus, eye anomalies, cleft palate/lip, ductal duct malformation characterized by proliferation and fibrosis in the portal areas of the liver and bile ducts, congenital heart anomalies, adrenal hypoplasia, a wide variety of anomalies such as male genital organ hypoplasia, male pseudohermaphroditism, cryptorchidism, pancreatic cysts and fibrosis, ureter agenesis, hypoplasia or duplication, bladder agenesis and hypoplasia, can also be seen $(5,6)$.

Since the risk of recurrence in the next children of mothers with a history of giving birth to a baby with MGS is $25 \%$; it is important to follow up and terminate the pregnancy in the next pregnancy. Nowadays, the main findings of this syndrome can be easily detected with a detailed examination using advanced USG devices. Definitive diagnosis of Meckel-Gruber syndrome is made by autopsy performed after delivery or after abortion (7).

Diagnosis in the early prenatal period can be overlooked therefore we report as a case of Meckel-Gruber syndrome which was defined by ultrasonography in the first trimester.

\section{CASE REPORT}

A 26 years old woman without consanguinity in her second pregnancy was referred to our perinatology clinic at 13th gestational week with a suspicion of encephalocele. Family history was unremarkable and both the patient and her partner are free from any medical comorbidities. Her first trimester screening test results were having low risk. In our examination, we demonstrated a large cystic encephalocele protruding from the fetal occipital bone on transabdominal ultrasonography (Figure 1).

The fetal kidneys were hyperechogenic and enlarged, consistent with bilateral cystic dysplasia (Figure 2). The hands were compatible with polydactyly (Figure 3). Amniotic fluid was adequate, but the bladder of the fetus could not be seen clearly. Karyotype analysis was suggested and termination of the pregnancy choice was offered but the patient did not accept both of them. According to the sonographic findings, our prenatal sonographic diagnosis was Meckel-Gruber syndrome.

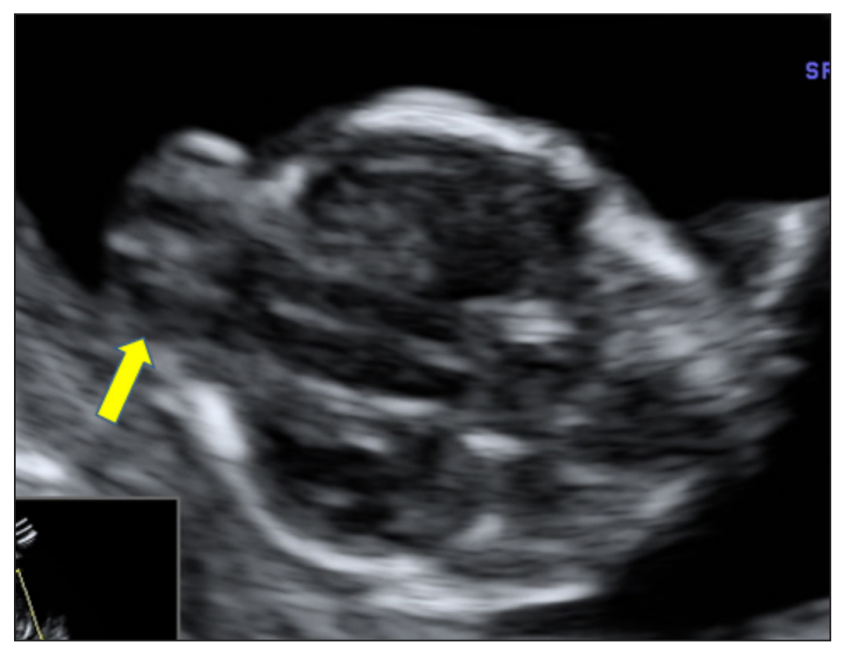

Figure 1: Occipital encephalocele

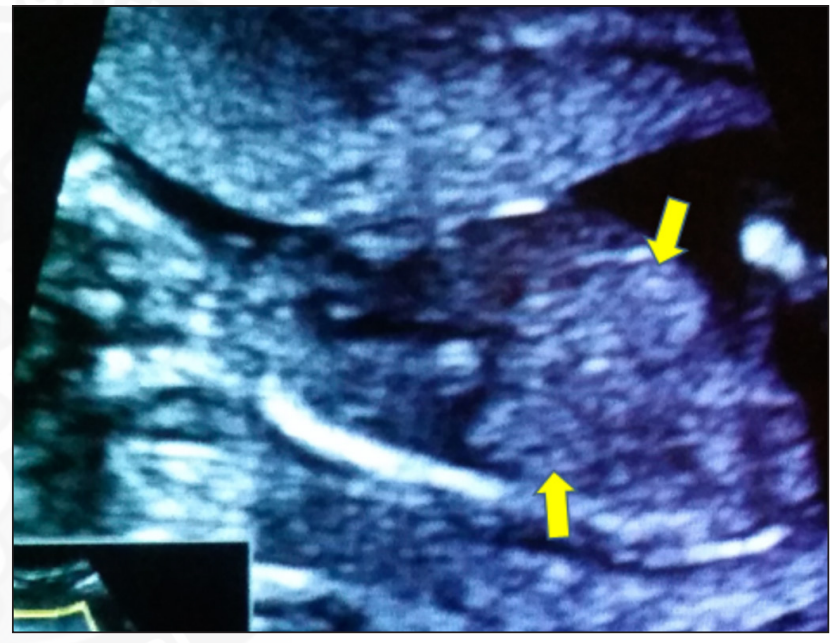

Figure 2: Dysplastic cystic kidneys

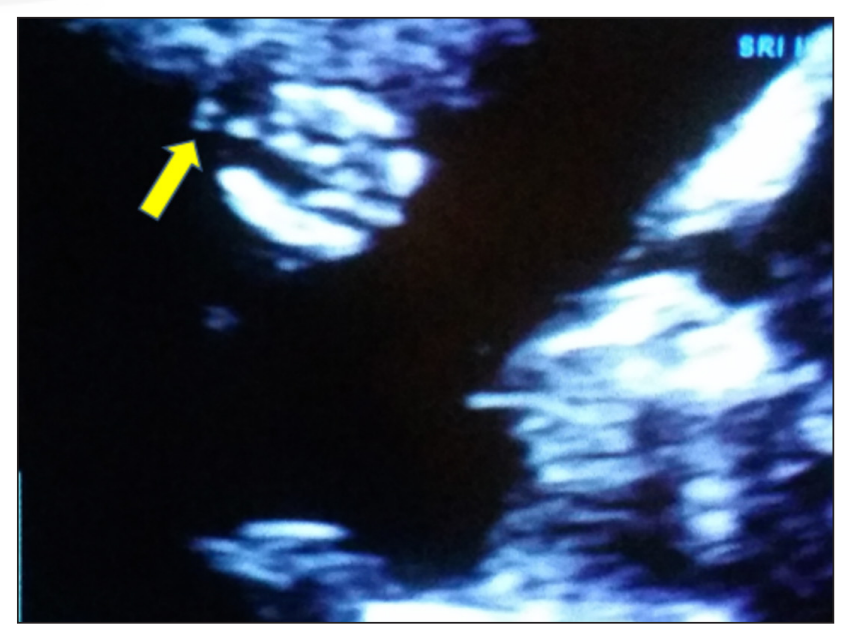

Figure 3: Polydactyly 


\section{DISCUSSION}

MGS, which was originally described by Meckel in 1822 and later by Gruber, is caused by the failure of mesodermal induction (8). The incidence of Meckel-Gruber syndrome (OMIM number. \# 249000) shows regional differences from $1: 3000$ to 2.6 per 100.000 live births in the world (9). It has an autosomal recessive genetic characteristic and carries a $25 \%$ risk of recurrence accordingly. An increased incidence has been reported in regions where consanguineous marriages are common (with 1 affected birth per 1,300) (8). Genetic mutations on chromosome 17q21-24 were determined in most of the cases. Pathogenesis of MGS is related to dysfunction of primary cilia $(10,11)$. Because of the elevated genetic heterogeneity potential, mapping is required on the other different locations. Additionally new genes accompanied with this syndrome were discovered and that explains phenotypical expression of this syndrome $(3,12)$. Jones et al. have demonstrated two separate mutations in the CC2D2A (MGS-related) gene by the next-generation sequencing (NGS) method in the abortion material to whom termination was applied at the $12^{\text {th }}$ gestational week with the pre-diagnosis of MKS due to the posterior occipital encephalocele and bilateral cystic kidney (13). Ridnoi et al. have reported the presence of heterogeneous pathogenic variants in the TXNDC15 gene with the whole-exome sequencing method in a MKS case with typical USG findings at the $12^{\text {th }}$ week of gestation (14).

Many fetal anomalies can be monitored by fetal USG starting from the $10^{\text {th }}-14^{\text {th }}$ weeks of pregnancy. Characteristic images on USG are dependent on gestational age. While the classical triad can be monitored better by USG before the $14^{\text {th }}$ week of pregnancy, it becomes difficult to diagnose with advanced oligohydramnios in the following weeks. Routine USG screening should be performed between 11 and 14 weeks in order to make prenatal diagnosis of MKS (9). In our case, a prenatal diagnosis was made ultrasonographically at the $13^{\text {th }}$ gestational week as well.

The incidence of renal cystic dysplasia in fetuses with Meckel-Gruber syndrome is $95-100 \%$, the incidence of occipital encephalocele is $60-80 \%$ and the incidence of postaxial polydactyly is $55-70 \%(15,16)$. In our case, occipital encephalocele, dysplastic cystic kidneys and polydactyly were observed in the ultrasonography performed at the $13^{\text {th }}$ gestational week. Extremity anomalies like clubfoot deformity, shortened limbs or bowing of the long bones could be distinguished. Additional anomalies that can be present in this syndrome include the central nervous system (CNS) (Dandy-Walker malformation, ventriculomegaly, hydrocephalus, microcephaly, agenesis of the corpus callosum), gastrointestinal system (omphalocele, hepatic fibrosis, hepatosplenomegaly, anorectal malformations), and cardiac anomalies (septal defects and coarctation of the aorta) $(9,11,17)$.
If multiple anomalies involving the CNS and the heart are found, one of the other conditions to be ruled out is trisomy 13, in which polydactyly, renal dysplasia, and CNS and cardiac anomalies can be found. Trisomy 13 and SmithLemli-Opitz syndrome should be denied in the differential diagnosis in cases including multiple anomalies (CNS, cardiac, renal and extremity). Therefore, a karyotype analysis should be ensured if there is a suspicion of Meckel-Gruber syndrome to exclude other chromosomal abnormalities (9).

The prognosis in Meckel-Gruber syndrome is poor and it is a lethal condition owing to dysplastic kidneys that result in severe oligohydramnios and pulmonary hypoplasia. Termination should be offered after the diagnosis and parents should receive genetic counselling and should be properly investigated by first trimester ultrasound scans for their subsequent pregnancies due to its autosomal recessive inheritance pattern and recurrence risk (9).

Currently, autopsy and postnatal-postabortal pathological examination are the only methods for definitive diagnosis in MGS cases. Although neonatal autopsy and genetic studies are gold standards for diagnosis, as mentioned above, the detection of two of the three main anomalies in the fetus by detailed ultrasonographic evaluation in the early period should be a warning for clinicians in terms of the pre-diagnosis of MGS and genetic counseling to be given to the family afterwards. The limitation of our study is that in our case, the family did not accept invasive procedures, wanted the continuation of the pregnancy, and continued the follow-up in another city, so advanced genetic and pathological evaluation for a definitive diagnosis could not be made.

As a result, MGS is a lethal disorder and its mortality is $100 \%$. In addition, it is a pathology with a high risk of recurrence $(25 \%)$ due to its autosomal recessively inheritance. Especially in families with anomaly history in previous pregnancies, early ultrasonographic evaluation and genetic counseling to be given to the family afterwards are important in management.

\section{Author Contrubitons}

The authors contributed equally.

\section{Conflicts of Interest}

No conflict of interest was declared by the authors.

\section{Financial Disclosure}

The authors declared that this study has received no financial support.

\section{Informed Consent}

The authors stated that the written consent was obtained from the patient presented with images in the study. 
Peer Review Process

Extremely peer-reviewed.

\section{REFERENCES}

1. Opitz JM, Howe JJ. The Meckel syndrome (dysencephalia spanchnocystica, the Grüber syndrome) Birth Defects 1969;2:167-179.

2. Alexiev BA, Lin X, Sun CC, Brenner DS. Meckel-Gruber syndrome: Pathologic manifestations, minimal diagnostic criteria, and differential diagnosis. Arch Pathol Lab Med 2006;130(8):1236-1238.

3. Eckmann-Scholz C, Jonat W, Zerres K, Ortiz-Brüchle N Earliest ultrasound findings and description of splicing mutations in Meckel-Gruber syndrome. Arch Gynecol Obstet 2012;286(4):917-921.

4. Balci S, Onol B, Erçal MD, Beksaç S, Erzen C, Akhan O. Meckel Gruber syndrome: A case diagnosed in utero. Turk $J$ Pediatr 1992;34(3):179-185.

5. Hartill V, Szymanska K, Sharif SM, Wheway G, Johnson CA. Meckel-Gruber Syndrome: An update on diagnosis, clinical management, and research advances. Front Pediatr 2017;5:244.

6. Khurana S, Saini V, Wadhwa V, Kaur H. Meckel-Gruber syndrome: Ultrasonographic and fetal autopsy correlation. J Ultrasound 2017;20(2):167-170.

7. Leneuve-Dorilas M, Ahounkeng Nanda P, Deshayes JL. Meckel-gruber syndrome: About an evocative case in French Guiana-When ultrasound is insufficient for accurate diagnosis in a complex syndrome. Clin Case Rep 2020;8(3):433-436.

8. Roy J, Pal M. Meckel gruber syndrome. J Clin Diagn Res 2013;7(9):2102-2103.
9. Barisic I, Boban L, Loane M, Garne E, Wellesley D, Calzolari E, Dolk H, Addor MC, Bergman JE, Braz P, Draper ES, Haeusler M, Khoshnood B, Klungsoyr K, Pierini A, Queisser-Luft A, Rankin J, Rissmann A, Verellen-Dumoulin C. Meckel-Gruber Syndrome: A population-based study on prevalence, prenatal diagnosis, clinical features, and survival in Europe. Eur J Hum Genet 2015;23(6):746-752.

10. Zhang M, Chang Z, Tian Y, Wang L, Lu Y. Two novel TCTN2 mutations cause Meckel-Gruber syndrome. J Hum Genet 2020;65(11):1039-1043.

11. Barker AR, Thomas R, Dawe HR. Meckel-Gruber syndrome and the role of primary cilia in kidney, skeleton, and central nervous system development. Organogenesis 2014;10(1):96107.

12. Paavola P, Salonen R, Baumer A, Schinzel A, Boyd PA, Gould $\mathrm{S}$, Meusburger $\mathrm{H}$, Tenconi R, Barnicoat A, Winter R, Peltonen L. Clinical and genetic heterogeneity in Meckel syndrome. Hum Genet 1997;101(1):88-92.

13. Jones D, Fiozzo F, Waters B, McKnight D, Brown S. Firsttrimester diagnosis of Meckel-Gruber syndrome by fetal ultrasound with molecular identification of CC2D2A mutations by next-generation sequencing. Ultrasound Obstet Gynecol 2014;44(6):719-721.

14. Ridnõi K, Šois M, Vaidla E, Pajusalu S, Kelder L, Reimand T, Ounap K. A prenatally diagnosed case of Meckel-Gruber syndrome with novel compound heterozygous pathogenic variants in the TXNDC15 gene. Mol Genet Genomic Med 2019;7(5):e614.

15. Salonen R. The Meckel syndrome: Clinicopathological findings in 67 patients. Am J Med Genet 1984;18(4):671-189.

16. Sel G. Meckel-Gruber Syndrome, case-report. JJ Clin Case Rep 2018; 5(4): 037.

17. Aguilar A, Meunier A, Strehl L, Martinovic J, Bonniere M, Attie-Bitach T, Encha-Razavi F, Spassky N. Analysis of human samples reveals impaired $\mathrm{SHH}$-dependent cerebellar development in Joubert syndrome/Meckel syndrome. Proc Natl Acad Sci USA 2012;109(42):16951-16956. 


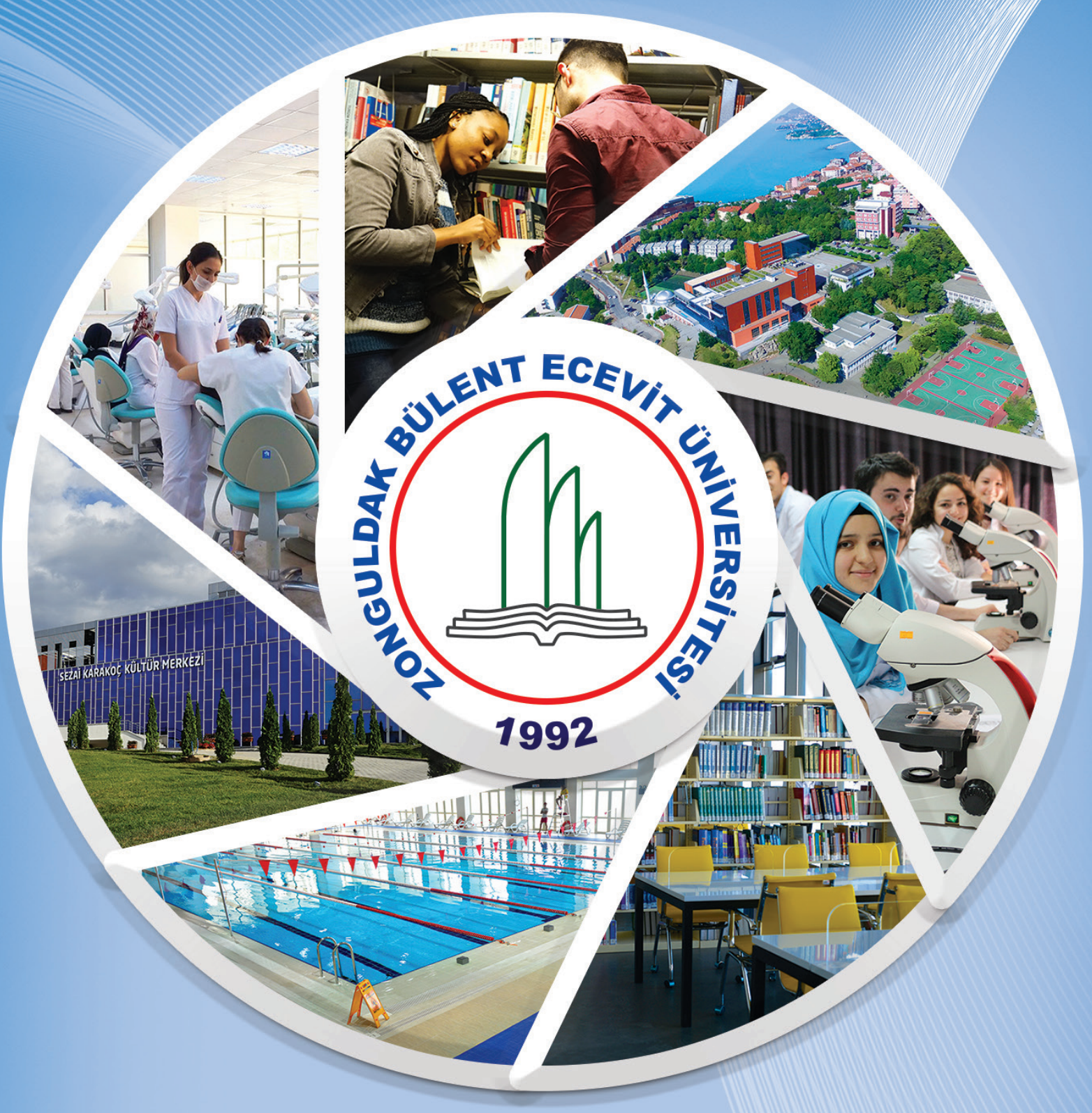

11 Farklı Kampüste

$\checkmark$ Çağdaş Eğitim Sınıfları

$\checkmark$ 7/24 Açık Kütüphaneler

$\checkmark$ Sosyal ve Kültürel Alanlar $\checkmark$ Tam Donanımlı Laboratuvarlar

- Modern Calıșma Salonları

$\checkmark$ Kafeler ve Yeșil Alanları ile

\section{Gelecek burada șekillenir...}

